\title{
Can Juniperus communis L. oil improve nephropathy in diabetic rats
}

\author{
Tahir Kahraman $^{1}$ (D) Mehmet Berkoz² (D), Oruc Allahverdiyev ${ }^{3}$ (D), Evan Abdulkarim Mahmood² (D), Metin Yildirim ${ }^{4}$ (D), \\ Serap Yalin ${ }^{4}$ (D) \\ ${ }^{1}$ Karabuk University, Faculty of Medicine, Department of Medical Biochemistry, Karabuk, Turkey. \\ ${ }^{2}$ Van Yuzuncu Yil University, Faculty of Pharmacy, Department of Biochemistry, Van, Turkey. \\ ${ }^{3}$ Van Yuzuncu Yil University, Faculty of Pharmacy, Department of Pharmacology, Van, Turkey. \\ ${ }^{4}$ Mersin University, Faculty of Pharmacy, Department of Biochemistry, Mersin, Turkey. \\ Correspondence Author: Mehmet Berkoz \\ E-mail: mehmet_berkoz@yahoo.com
}

Received: $22.03 .2019 \quad$ Accepted: 07.10.2019

\begin{abstract}
Objective: Juniperus communis L. (J. communis) is a shrub belonging to family Cupressaceae L. mainly growth in Eurasia. The antioxidant and antidiabetic activity of aqueous extract of $J$. communis L. berries indicated benefits as a potent antidiabetic in streptozotocin induced diabetic albino rats. This study was carried out to determine whether J. communis L. oil supplement will effectively manage renal dysfunction in diabetic rats.

Methods: Twenty eight rats were divided into 4 equal groups as follows; control group, diabetic group (45 mg/kg, i.p. streptozotocin) , J. communis L. oil ( $200 \mathrm{mg} / \mathrm{kg}$ ) treated group, and diabetic + . communis L. oil $(200 \mathrm{mg} / \mathrm{kg})$ treated group. At the end of the experimental period, all rats were sacrificed and renal function parameters such as kidney antioxidant and lipid peroxidation markers and serum glucose, HbA1c, creatinine, serum urea, blood urea nitrogen (BUN), and serum total protein levels were measured in all groups.

Results: HbA1c, serum glucose, urea, creatinine, BUN and, kidney lipid peroxidation levels increased $(p<0.05)$, but serum total protein and antioxidant levels decreased in diabetic group comparing with control group $(p<0.05)$. Furthermore, HbA1c, serum glucose, urea, creatinine and BUN and, kidney lipid peroxidation levels decreased and also, serum total protein and antioxidant levels increased in diabetic group treated with J. communis L. oil comparing with diabetic group ( $p<0.05)$.
\end{abstract}

Conclusion: This study has provided that J. communis L. oil provide a protective effect on the kidney as evidenced by an improvement of the renal function tests as well as reduction in oxidative stress parameters in experimental diabetic nephropathy model.

Keywords: Juniperus communis L., diabetes, nephropathy, antioxidant, lipid peroxidation, oxidative stress

\section{INTRODUCTION}

Diabetes, characterized by hyperglycemia and metabolic disturbance on lipids, carbohydrates, and proteins, affect the life quality of patients by bringing huge pressure to society and public health (1). Nearly $2.2 \%$ of total death in the world is caused by diabetes (2). Type II diabetes, considered as the common form of diabetes, will affect the health of 8 billion people in the world till 2025 (3). Persistent hyperglycemia in diabetes mellitus (DM) leads to the development of secondary complications including neuropathy, nephropathy, and retinopathy (2). Diabetic nephropathy is the major cause of end-stage renal disease with high mortality and morbidity (4). A major clinical manifestation of diabetic nephropathy is that microalbuminuria follows macroalbuminuria and further leads to renal dysfunction which is the reduced capacity of the kidney to excrete metabolic products which accumulate in the body system and can be detected via renal function test (5). Therefore, due to numerous degenerative effects of untreated DM on human system, numerous researches have been carried out and still ongoing for the management and treatment of DM. Management of DM usually involves adjustment of the diet of the individual, exercise at regular interval, health education, measurement of blood glucose level on a regular level, and, in case of insulin dependent DM, supplementary therapy with insulin $(6,7)$.

Juniperus communis $\mathrm{L}$. is a shrub belonging to family Cupressaceae L. mainly growth in Eurasia, North Africa and North America at an altitude of 1500-4000. Fruit is subspherical, purplish-black and seed contained 2-3 layers of thin-walled cells. The seeds and fruits of the plant contain camphene, $\mathrm{d}$ - $\alpha$-pinene, formic acid, acetic acid, wax, gum, cyclohexinol, terpene, ascorbic acid, dihydrojunene, cadinene, juniper, and camphor $(8,9)$. J. communis L. berry oil mainly contained monoterpene hydrocarbons such as $\alpha$-pinene $(51.4 \%), \beta$-pinene $(5.0 \%)$, sabinene (5.8\%), and myrcene (8.3\%) (10). J. communis L. can be used (traditionally) for renal suppression, acute 
and chronic cystitis, catarrh of the bladder, albuminuria, leucorrhoea, and amenorrhoea. J. communis L. fruit can be used as being antiseptic, stimulant, and styptic. It can also be used in the treatment of migraine, infantile tuberculosis, rheumatic and painful swellings, chronic Bright's disease, piles, and nephrotic dropsy of children (11). The plant was reported to have analgesic, antibacterial, hepatoprotective, antihypercholesterolemic, antiinflammatory, antioxidant, antidiabetic, antihyperlipidemic, anticataleptic, and antimicrobial activities (9).

The antioxidant and antidiabetic activity of aqueous extract of J. communis $\mathrm{L}$. berries indicated potential benefits as a potent antidiabetic in streptozotocin (STZ) induced diabetic albino rats (12). J. communis L. berries was also a good scavenger for nitric oxide radicals and has a potential source of natural antioxidant. J. communis L. berry has also nutraceutical uses and is used in treatment of hypercholesterolemia and hyperglycemia, and also, as a nutritional supplementation, it can be prescribed as food appendage for coronary artery disease patients along with their regular medicines (9).

Therefore, since renal dysfunction has been on increase in diabetic patients without a promising remedy, this study was carried out to determine whether dietary intake of $J$. communis L. oil will protectively or effectively manage renal dysfunction via examination of renal function parameters such as kidney antioxidant and oxidative stress markers and serum creatinine, serum urea, blood urea nitrogen (BUN), and serum total protein estimation in diabetic rats.

\section{METHODS}

\subsection{Animals}

All adult male Wistar albino rats were purchased from the Animal Experimental Center of Van Yuzuncu Yil University, aged 3-4 months with weights ranging from 300 to $350 \mathrm{~g}$. Ethical approval of the study was obtained from Van Yuzuncu Yil University Ethical Commission for Animal Experiments (Decision number: 2015/14, Date: 24.12.2015). All animals were housed in a comfortable environment ( $12 \mathrm{~h}$ light-dark cycle, $20-25{ }^{\circ} \mathrm{C}$ temperature, $40-60 \%$ humidity) and fed with rodent chow and water ad libitum.

\subsection{Reagents}

All the chemicals and reagents were supplied by SigmaAldrich, Merck or other standard suppliers.

\subsection{Preparation of J. communis L. oil}

The fresh air dried J. communis L. berries (300-400 g) were subjected to water-distillation boiling $\left(>100{ }^{\circ} \mathrm{C}\right)$ for $3 \mathrm{~h}$ by using a Clevenger-type apparatus. The obtained essential oil was dried over anhydrous sodium sulfate and after filtration through Whatman filter paper (No. 1) stored at $4{ }^{\circ} \mathrm{C}$ until tested.

\subsection{Experimental Procedure}

Type 1 DM was induced by a single intraperitoneal (i.p.) injection of $45 \mathrm{mg} / \mathrm{kg} \mathrm{STZ}$ to overnight fasted rats. STZ solution was freshly prepared by dissolving in $0.1 \mathrm{M}$ cold citrate buffer ( $\mathrm{pH} 4.5$ ). In spite of the possibility of sudden hyperglycaemic shock following STZ injection in animals, this dose was considered appropriate. Diabetes was confirmed through the determination of blood glucose levels at $72 \mathrm{hr}$ using OneTouch UltraMini glucometer (LifeScan, Inc., California, USA). Rats with blood glucose levels higher than $300 \mathrm{mg} / \mathrm{dL}$ were considered diabetic and selected for further experiments. Diabetes was further verified by measuring blood glucose levels 7 days after STZ injection. Normal control rats received a single i.p. dose of physiological saline. Twenty eight rats ( 14 diabetic and 14 normal) were divided into 4 equal groups ( $n=7$ ) as follows; Group I (Control group): Nondiabetic rats received physiological saline orally for 21 days, Group II (Diabetic group): Diabetic rats received physiological saline by oral gavage for 21 days, Group III (J. communis L. oil group): Nondiabetic rats received $J$. communis L. oil $(200 \mathrm{mg} / \mathrm{kg})$ dissolved in $5 \% \mathrm{Na}-\mathrm{CMC}$ by oral gavage for 21 days, and Group IV (Diabetic+J. communis L. oil group): Diabetic rats received J. communis L. oil $(200 \mathrm{mg} / \mathrm{kg}$ ) dissolved in $5 \% \mathrm{Na}-\mathrm{CMC}$ by oral gavage for 21 days. Ethical approval of the study was obtained from Ethical approval of the study was obtained from Van Yuzuncu Yil University Ethical Commission for Animal Experiments (Decision number: 2015/14, Date: 24.12.2015).

\subsection{Preparation of Serum and Kidney Tissue}

At the end of the experimental period, all rats were fasted for 12 hours before being sacrificed by intraperitoneal injection of ketamine hydrochloride (15 mg/kg, i.p.) and xylazine (10 $\mathrm{mg} / \mathrm{kg}$, i.p.). Kidney tissues were immediately excised from the surrounding tissues and were subsequently weighed. Immediately following collection, kidney tissues were washed with ice-cold phosphate-buffered saline (PBS). The samples were homogenized in phosphate buffer $(25 \mathrm{mM}$, $\mathrm{pH} 7.4$ ) to make approximately $10 \% \mathrm{w} / \mathrm{v}$ homogenates. The homogenates were centrifuged at $1700 \mathrm{rpm}$ for $10 \mathrm{~min}$, and the supernatant was collected and stored at $-70^{\circ} \mathrm{C}$ for further biochemical analysis. The protein concentration in the supernatant was estimated by Lowry et al's method.

\subsection{Serum Preparation and Biochemical Measurements in Serum}

Blood samples were placed in dry test tubes and were allowed to coagulate at ambient temperature for $30 \mathrm{~min}$. Serum was separated by centrifugation at $3500 \mathrm{rpm}$ for 15 min. Enzymatic colorimetric kits (Bioscience, Cambridge, UK) were used to measure serum glucose, total protein, creatinine, urea, and blood urea nitrogen (BUN) levels. 


\subsection{Measurement of serum glycosylated hemoglobin (HbA1c) Level}

Serum $\mathrm{HbA1c}$ levels were measured in whole blood using an automated chemistry analyzer (Roche Cobas Integra 800 Chemistry analyzer, Roche Diagnostics, Mannheim, Germany).

\subsection{Measurement of lipid peroxidation and antioxidant enzyme activities in kidney}

The supernatants obtained after this procedure was used for the analyses of MDA, NO, and GSH levels and SOD and catalase activities.

MDA Level: MDA reacts with thiobarbituric acid (TBA), giving a spectroscopically readable final product at $532 \mathrm{~nm}$. MDA levels were expressed as $\mathrm{nmol} / \mathrm{mg}$ protein using the extinction coefficient value of $1.56 \times 10^{5} \mathrm{M}^{-1} \cdot \mathrm{cm}^{-1}$ (13).

Nitrite/Nitrate levels: Tissue nitric oxide is rapidly converted to nitrate and nitrite in aqueous solutions. Hence, for accurate assay of the total nitric oxide, both nitrate and nitrite levels must be determined. Tissue nitrate is chemically reduced to nitrite by granulated cadmium. Griess reagent reacts with total nitrite, and forms a coloured complex. The intensity of the colour is proportional to the concentration of the nitrite in the sample, which can be measured spectrophotometrically (14).

GSH level: GSH analysis was performed according to the method reported by Beutler et al (15). In this method, all proteins that do not carry the sulfhydryl in the tissue homogenates are precipitated. In the obtained clear liquid, the yellow complex formed by 5,5'-Dithiobis (2-nitrobenzoic acid) (DTNB) and sulfhydryl groups is measured colorimetrically at a wavelength of $412 \mathrm{~nm}$.

SOD Activity: The principle of measurement of SOD enzyme activity, which accelerates the aquatic and molecular oxygen dismutation of endogenous and exogenous sources of toxic superoxide radicals generated during the production of oxidative pathway energy, is based on the spectrophotometric measurement of superoxide radicals which are released by xanthine oxidase in the presence of xanthine in the presence of nitroblue tetrazolium (NBT) at $560 \mathrm{~nm}$ according to Sun et al (16).

Catalase Activity: The activity of the enzyme catalase was analysed according to Aebi method (17), measuring the initial rate of $\mathrm{H} 2 \mathrm{O} 2$ decomposition at $240 \mathrm{~nm}$. Catalase activity was expressed as $\mathrm{U} / \mathrm{mg}$ protein.

Tissue Protein Content: In the alkaline solution, a copperprotein complex is formed. This complex reduces the phosphomolybdate phosphotungstate reagent (FolinCiocalteus-Phenol Reagent) and forms a dark blue color. The resulting darkness is directly proportional to the protein concentration in the medium according to Lowry el al (18).

\subsection{Statistical Analysis}

Statistical analysis was performed by one-way analysis of variance (ANOVA) plus Tukey post-hoc analysis. Statistical analyses were performed using the SPSS software version 15.0 (SPSS Inc., Illinois, USA). All data are indicated as means \pm SD. In addition, increases or decreases between the groups are indicated as percentages. $p<0.05$ was considered statistically significant.

\section{RESULTS}

Compared with Group I, the enhanced serum glucose, $\mathrm{HbA1c}$, creatinine, urea, and BUN levels were observed after STZ injection in Group II $(p<0.05)$. There was a significant decrease in serum total protein level of diabetic rats when compared to control group $(p<0.05)$. J. communis L. oil at $200 \mathrm{mg} / \mathrm{kg}$ resulted in $12.7 \%$ reduction of serum $\mathrm{HbA} 1 \mathrm{c}$ level, $73.6 \%$ reduction of serum glucose level, $19.2 \%$ reduction of serum creatinine level, $28.5 \%$ reduction of serum urea level, $28.5 \%$ reduction of BUN level, on the other hand, $16.4 \%$ augmentation of serum total protein level compared with the diabetic group. All parameters showed significant differences between Group II and Group III $(p<0.05)$. Results on serum glucose, $\mathrm{HbA} 1 \mathrm{c}$, total protein, creatinine, urea, and BUN levels were shown in Table 1.

Table 1. Effect of administration of J. communis L. oil for 21 days on serum glucose, serum $H b A 1 c$, serum creatinine, serum urea, BUN, and serum total protein levels in diabetic rats.

\begin{tabular}{|l|c|c|c|c|}
\hline $\begin{array}{l}\text { Serum } \\
\text { glucose } \\
\text { level (mg/dL) }\end{array}$ & $62.54 \pm 7.94$ & $397.77 \pm 47.2^{\mathrm{a}}$ & $70.51 \pm 8.93$ & $105.08 \pm 12.85^{\mathrm{a}, \mathrm{b}}$ \\
\hline $\begin{array}{l}\text { Serum } \\
\text { HbA1c level } \\
\text { (\%) }\end{array}$ & $5.8 \pm 0.47$ & $7.1 \pm 0.43^{\mathrm{a}}$ & $5.6 \pm 0.33$ & $6.2 \pm 0.38^{\mathrm{b}}$ \\
\hline $\begin{array}{l}\text { Serum } \\
\text { creatinine } \\
\text { level (mg/dL) }\end{array}$ & $0.57 \pm 0.04$ & $0.73 \pm 0.06^{\mathrm{a}}$ & $0.61 \pm 0.08$ & $0.59 \pm 0.07^{\mathrm{b}}$ \\
\hline $\begin{array}{l}\text { Serum urea } \\
\text { level (mg/dL) }\end{array}$ & $36.7 \pm 4.59$ & $49.84 \pm 4.76^{\mathrm{a}}$ & $38.09 \pm 4.07$ & $35.64 \pm 4.15^{\mathrm{b}}$ \\
\hline $\begin{array}{l}\text { BUN level } \\
\text { (mg/dL) }\end{array}$ & $17.14 \pm 1.35$ & $23.26 \pm 1.68^{\mathrm{a}}$ & $17.77 \pm 2.39$ & $16.63 \pm 2.24^{\mathrm{b}}$ \\
\hline $\begin{array}{l}\text { Serum total } \\
\text { protein } \\
\text { level (g/dL) }\end{array}$ & $8.19 \pm 0.64$ & $6.75 \pm 0.46^{\mathrm{c}}$ & $8.47 \pm 0.73$ & $7.86 \pm 0.55^{\mathrm{d}}$ \\
\hline
\end{tabular}

a Significantly higher than Group I ( $p<0.05),{ }^{b}$ Significantly lower than Group II ( $p<0.05)$, ' Significantly lower than Group I ( $p<0.05),{ }^{d}$ Significantly higher than Group II ( $p<0.05)$

Oxidative stress has been implicated in inflammation which is directly related to the level of MDA, NO and GSH and activities of SOD and catalase. Low tissue concentrations of SOD, GSH, and catalase and high tissue concentrations of MDA and NO were noted in Group II compared with Group I $(p<0.05)$. J. 
communis L. oil at dose of $200 \mathrm{mg} / \mathrm{kg}$ enhanced $73.7 \%$ of SOD activity $(p<0.05), 52.7 \%$ of catalase activity $(p<0.05)$ and $38.8 \%$ of GSH level $(p<0.05)$, besides this, decreased $31.4 \%$ of MDA level $(p<0.05)$ and $29.8 \%$ of NO level $(p<0.05)$ in kidney tissue of diabetic rats. Results on SOD, and catalase activities and GSH, MDA, and NO levels in kidney tissue were shown in Table 2.

Table 2. Effect of administration of J. communis L. oil for 21 days on $M D A, N O$, and GSH levels and SOD and catalase activities in diabetic rats.

\begin{tabular}{|l|c|c|c|c|}
\hline $\begin{array}{l}\text { MDA level } \\
\text { (nmol/mg } \\
\text { protein) }\end{array}$ & $28.73 \pm 3.97$ & $46.51 \pm 6.84^{\mathrm{a}}$ & $30.71 \pm 4.87$ & $31.92 \pm 4.5^{\mathrm{b}}$ \\
\hline $\begin{array}{l}\text { NO level } \\
\text { (nmol/mg } \\
\text { protein) }\end{array}$ & $14.62 \pm 1.57$ & $22.05 \pm 2.47^{\mathrm{a}}$ & $15.18 \pm 2.93$ & $15.47 \pm 2.19^{\mathrm{b}}$ \\
\hline $\begin{array}{l}\text { GSH level } \\
\text { (nmol/mg } \\
\text { protein) }\end{array}$ & $69.81 \pm 5.35$ & $51.64 \pm 4.43^{\mathrm{c}}$ & $70.39 \pm 8.65$ & $71.68 \pm 6.03^{\mathrm{d}}$ \\
\hline $\begin{array}{l}\text { SOD } \\
\text { activity } \\
\text { (U/mg } \\
\text { protein) }\end{array}$ & $3.91 \pm 0.38$ & $2.13 \pm 0.27^{\mathrm{c}}$ & $3.76 \pm 0.49$ & $3.7 \pm 0.42^{\mathrm{d}}$ \\
\hline $\begin{array}{l}\text { Catalase } \\
\text { activity } \\
\text { (U/mg } \\
\text { protein) }\end{array}$ & $395.62 \pm 37.61$ & $264.44 \pm 31.95^{\mathrm{c}}$ & $388.52 \pm 40.17$ & $403.86 \pm 37.51^{\mathrm{d}}$ \\
\hline
\end{tabular}

${ }^{a}$ Significantly higher than Group I ( $\left.p<0.05\right),{ }^{b}$ Significantly lower than Group II ( $p<0.05)$, ' Significantly lower than Group I $(p<0.05),{ }^{d}$ Significantly higher than Group II $(p<0.05)$

\section{DISCUSSION}

Diabetic nephropathy like any other chronic diabetic complications is caused by various reasons, including poor glycemic control, high blood pressure, and high cholesterol (especially hypertriglyceridemia) (19). In this study, it was found that $J$. communis L. oil treatment could decrease the level of serum $\mathrm{HbA} 1 \mathrm{c}$ and glucose levels, therefore $J$. communis L. oil could inhibit the development of diabetic nephropathy.

Renal dysfunction as a result of DM can be assessed by serum creatinine, urea, BUN, and total protein. Therefore, this suggested that there is strong relationship between these parameters and renal dysfunction. Thus, an increase in creatinine, urea, and BUN occurs when there is renal dysfunction or damage. The increment in serum creatinine, urea, and BUN observed in this study clearly indicated that DM causes damage or dysfunction of the kidney in diabetics. Hence, the results of this study were in accordance with various studies which showed raised serum creatinine, urea, and BUN levels in diabetic patients (20). Also, in this study, there were increased levels of these kidney function parameters (except serum total protein level) in diabetic control group when compared to normal control and diabetic test group. The increment observed in diabetic control group revealed that untreated DM caused severe dysfunction of the kidney compared to treated DM through dietary consumption of J. communis L. oil.

According to previous research, J. communis L. oil were reported to have renoprotective and regenerative effects on the kidney of hypercholesterolemic rats (21). Therefore, it is not unreasonable to suggest that J. communis L. oil has remedial and protective effects on the kidneys of diabetic rats.

However, the remedial effect of J. communis L. oil may probably be due to the earlier reported antioxidant and antiinflammatory properties of $J$. communis $L$. oil as a result of its chemical components especially medium chain fatty acids $(22,23)$.

In addition, in this study, it was observed that there was a decrease in serum total protein of diabetic group compared to control and diabetic group treated with J. communis L. oil. This was probably because of the damaging effects DM has on the kidney tissues of diabetic control group which was minimized in diabetic test group as a result of dietary consumption of J. communis L. oil.

Kidney is abnormally sensitive to oxidative stress; under the condition of high glucose, reactive oxygen species (ROS) can induce renal cell apoptosis and drop from basement membrane, causing damaged glomerular filtration membrane integrity and even proteinuria; moreover, thereby promoting the development of diabetic nephropathy (24). There are mainly several kinds of antioxidant defense system, including glutathione (GSH), catalase, and superoxide dismutase (SOD) (25). Unfortunately, in some cases antioxidant defense system mentioned cannot overcome the elevation of oxidative stress. Therefore, an excess oxidative stress can attack the cell components especially the polyunsaturated fatty acids leading to the increase level of MDA, a lipid peroxidation product (26). The role of nitric oxide in diabetic nephropathy is a rather controversial issue. Some researchers have reported that nitric oxide increased kidney injury through its reactions with a superoxide radical and generation of a cytotoxic peroxynitrite $(27,28)$. The impairment in the oxidant/antioxidant equilibrium also induces tissue damage and diabetic complications (24). In this study, the level of GSH and activities of SOD and CAT and the content of MDA in serum and kidney tissue for analyzing systemic and local ability to clean the free radicals were detected. Compared with Group I, the level of GSH and activities of catalase and SOD in kidney tissue was decreased and level of MDA and NO was increased in diabetic rats; therefore the ability of scavenging free radicals was destroyed in diabetic nephropathy model. After J. communis L. oil treatment, the level of GSH and activities of catalase and SOD in kidney tissue were obviously increased, and the levels of MDA and NO were obviously decreased, therefore J. communis L. oil treatment was promoted to scavenge free radicals in kidney through regulating enzymatic and non-enzymatic antioxidants. 


\section{CONCLUSION}

It could be concluded that J. communis L. oil succeeded in controlling hyperglycemia in rats with STZ induced diabetes. Furthermore, this study has provided direct evidence of a link between DM and diabetic nephropathy and demonstrated that $J$. communis L. oil provide a protective effect on the kidney as evidenced by an improvement of the renal function tests as well as reduction in oxidative stress parameters.

\section{REFERENCES}

[1] Ramachandran S, Rajasekaran A, Adhirajan N. In vivo and in vitro antidiabetic activity of Terminalia paniculata bark: An evaluation of possible phytoconstituents and mechanisms for blood glucose control in diabetes. ISRN Pharmacol 2013; 2013:484675.

[2] Sheikh BA, Pari L, Rathinam A, Chandramohan R. Transanethole, a terpenoid ameliorates hyperglycemia by regulating key enzymes of carbohydrate metabolism in streptozotocin induced diabetic rats. Biochimie 2015; 112:57-65.

[3] Dyson T. World food trends and prospects to 2025. Proc Natl Acad Sci U S A. 1999; 96:5929-5936.

[4] Zhu K, Kakehi T, Matsumoto M, Iwata K, Ibi M, Ohshima Y, Zhang J, Liu J, Wen X, Taye A, Fan C, Katsuyama M, Sharma $\mathrm{K}$, Yabe-Nishimura C. NADPH oxidase NOX1 is involved in activation of protein kinase $\mathrm{C}$ and premature senescence in early stage diabetic kidney. Free Radic Biol Med 2015; 83:2130.

[5] Dey N, Bera A, Das F, Ghosh-Choudhury N, Kasinath BS, Choudhury GG. High glucose enhances microRNA-26a to activate mTORC1 for mesangial cell hypertrophy and matrix protein expression. Cell Signal 2015; 27:1276-1285.

[6] Lin YC, Chang YH, Yang SY, Wu KD, Chu TS. Update of pathophysiology and management of diabetic kidney disease. J Formos Med Assoc 2018; 117:662-675.

[7] Yakush Williams JK. Management strategies for patients with diabetic kidney disease and chronic kidney disease in diabetes. Nurs Clin North Am 2017; 52:575-587.

[8] Clifton SJ, Ward LK, Ranner DS. The status of juniper Juniperus communis L. in North-East England. Biol Conserv 1997; 79:6777.

[9] Bais S, Gill NS, Rana N, Shandil S. A phytopharmacological review on a medicinal plant: Juniperus communis. Int Sch Res Notices 2014; 2014:634723.

[10] Höferl M, Stoilova I, Schmidt E, Wanner J, Jirovetz L, Trifonova D, Krastev L, Krastanov A. Chemical composition and antioxidant properties of Juniper Berry (Juniperus communis L.) essential oil. action of the essential oil on the antioxidant protection of Saccharomyces cerevisiae model organism. Antioxidants (Basel) 2014; 3:81-98.

[11] Tavares WR, Seca AML. The current status of the pharmaceutical potential of Juniperus L. metabolites. Medicines (Basel) 2018; $5: 81$.
[12] Orhan N, Hoçbaç S, Orhan DD, Asian M, Ergun F. Enzyme inhibitory and radical scavenging effects of some antidiabetic plants of Turkey. Iran J Basic Med Sci 2014; 17:426-432.

[13] Yagi K. Simple procedure for specific enzyme of lipid hydroperoxides in serum or plasma. Methods Mol Biol 1998; 108:107-110.

[14] Miranda KM, Espey MG, Wink DA. A rapid, simple spectrophotometric method for simultaneous detection of nitrate and nitrite. Nitric Oxide 2001; 5:62-71.

[15] Beutler E, Duron O, Kelly BM. Improved method for the determination of blood glutathione. J Lab Clin Med 1963; 61:882-888.

[16] Sun Y, Oberley LW, Ying L. A simple method for clinical assay of superoxide dismutase. Clin Chem 1988; 34:497-500.

[17] Aebi H. Catalase in vitro. Methods Enzymol 1984; 105:121126.

[18] Lowry OH, Rosebrough NJ, Farr AL, Randall RJ. Protein measurement with the Folin phenol reagent. J Biol Chem 1961; 193:265-275.

[19] Misra A, Sattar N, Tandon N, Shrivastava U, Vikram NK, Khunti K, Hills AP. Clinical management of type 2 diabetes in south Asia. Lancet Diabetes Endocrinol 2018; 6:979-991.

[20] Adler Al, Stevens RJ, Manley SE, Bilous RW, Cull CA, Holman RR. Development and progression of nephropathy in type 2 diabetes: the United Kingdom Prospective Diabetes Study (UKPDS 64). Kidney Int 2003; 63:225-232.

[21] Akdogan M, Koyu A, Ciris M, Yildiz K. Anti-hypercholesterolemic activity of $\mathrm{J}$. communis oil in rats: a biochemical and histopathological investigation. BioMed Res 2012; 23:321-328.

[22] Jones SM, Zhong Z, Enomoto N, Schemmer P, Thurman RG. Dietary juniper berry oil minimizes hepatic reperfusion injury in the rat. Hepatology 1998; 28:1042-1050.

[23] Han X, Parker TL, Benavente C. Anti-inflammatory activity of Juniper (Juniperus communis) berry essential oil in human dermal fibroblasts. Cogent Medicine 2017; 4:1-7.

[24] Susztak K, Raff AC, Schiffer M, Böttinger EP. Glucose-induced reactive oxygen species cause apoptosis of podocytes and podocyte depletion at the onset of diabetic nephropathy. Diabetes 2006; 55:225-233.

[25] Gupta V, Lahiri SS, Sultana S, Kumar R. Mechanism of action of Rhodiola imbricata Edgew during exposure to cold, hypoxia and restraint (C-H-R) stress induced hypothermia and post stress recovery in rats. Food Chem Toxicol 2009; 47:12391245.

[26] Buldanlioglu S, Turkmen S, Ayabakan HB, Yenice N, Vardar $M$, Dogan S. Nitric oxide, lipid peroxidation and antioxidant defence system in patients with active or inactive Behçet's disease. Br J Dermatol 2005; 153:526-530.

[27] Di Marco E, Jha JC, Sharma A, Wilkinson-Berka JL, JandeleitDahm KA, de Haan JB. Are reactive oxygen species still the basis for diabetic complications? Clin Sci (Lond) 2015; 129:199-216.

[28] Tessari P. Nitric oxide in the normal kidney and in patients with diabetic nephropathy. J Nephrol 2015; 28:257-268.

How to cite this article: Kahraman T, Berkoz M, Allahverdiyev O, Mahmood EA, Yildirim M, Yalin S. Can Juniperus communis L. oil improve nephropathy in diabetic rats. Clin Exp Health Sci 2020; 10: 120-124. DOI: 10.33808/clinexphealthsci.543272 